OPEN ACCESS

Edited by:

Frederick Jeffrey Kaskel, Children's Hospital at Montefiore,

United States

Reviewed by:

Juan C. Kupferman

Maimonides Medical Center

United States

Jan Halbritter,

Leipzig University, Germany

Vera Hermina Koch,

University of São Paulo, Brazi

*Correspondence:

Rasheed A. Gbadegesin rasheed.gbadegesin@duke.edu

Specialty section

This article was submitted to

Pediatric Nephrology,

a section of the journal

Frontiers in Pediatrics

Received: 26 November 2018

Accepted: 11 January 2019

Published: 29 January 2019

Citation:

Lane BM, Cason R, Esezobor Cl and

Gbadegesin RA (2019) Genetics of Childhood Steroid Sensitive Nephrotic

Syndrome: An Update.

Front. Pediatr. 7:8.

doi: 10.3389/fped.2019.00008

\section{Genetics of Childhood Steroid Sensitive Nephrotic Syndrome: An Update}

\author{
Brandon M. Lane ${ }^{1,2}$, Rachel Cason ${ }^{1}$, Christopher Imokhuede Esezobor ${ }^{3}$ and \\ Rasheed A. Gbadegesin ${ }^{1,2 *}$
}

${ }^{1}$ Division of Nephrology, Departments of Pediatrics, Duke University Medical Center, Durham, NC, United States, ${ }^{2}$ Duke Molecular Physiology Institute, Duke University Medical Center, Durham, NC, United States, ${ }^{3}$ Department of Pediatrics,

College of Medicine of the University of Lagos, Lagos, Nigeria

Advances in genome science in the last 20 years have led to the discovery of over 50 single gene causes and genetic risk loci for steroid resistant nephrotic syndrome (SRNS). Despite these advances, the genetic architecture of childhood steroid sensitive nephrotic syndrome (SSNS) remains poorly understood due in large part to the varying clinical course of SSNS over time. Recent exome and genome wide association studies from well-defined cohorts of children with SSNS identified variants in multiple MHC class II molecules such as HLA-DQA1 and HLA-DQB1 as risk factors for SSNS, thus stressing the central role of adaptive immunity in the pathogenesis of SSNS. However, evidence suggests that unknown second hit risk loci outside of the MHC locus and environmental factors also make significant contributions to disease. In this review, we examine what is currently known about the genetics of SSNS, the implications of recent findings on our understanding of pathogenesis of SSNS, and how we can utilize these results and findings from future studies to improve the management of children with nephrotic syndrome.

Keywords: nephrotic syndrome, SSNS, podocyte, MHC class II LOCUS, HLA DQ/DR

\section{CHILDHOOD NEPHROTIC SYNDROME OVERVIEW}

Nephrotic syndrome (NS) is the most common glomerular disease seen in the pediatric age group. It is the second most common kidney disease seen in pediatric nephrology clinic, the most common being congenital malformations of the kidney and the urinary tract. It is characterized by massive proteinuria, hypoalbuminemia, peripheral edema and hyperlipidemia (1). The prevalence and incidence of NS is unknown, however estimates from different studies suggest that its incidence may be about 1.5 to 16.9 cases per 100,000 children and prevalence is about 16 cases per 100,000 children. Its incidence and prevalence varies between different geographical regions of the world and ethnicities (2). In a recent study in Ontario, Canada, Banh et al. reported incidence rate of 2.40, 15.83, 1.81, 3.01 for children of European, South Asian, East/Southeast Asian, and African ancestries, respectively (3).

Nephrotic syndrome in children is generally classified into steroid sensitive nephrotic syndrome (SSNS) and steroid resistant nephrotic syndrome (SRNS) based on the initial response to corticosteroid therapy at presentation. This classification resulted from the International Study of Kidney Disease in Children (ISKDC) studies in the 1970s, which showed that irrespective of morphological changes on kidney biopsy, the most important prognostic factor in NS is the 
response to corticosteroid and other immunosuppressive therapies (4). Children with SSNS have excellent prognosis with $>95 \%$ unlikely to progress to end stage kidney disease (ESKD) as long as they remain therapy responsive. On the other hand, the majority of children with SRNS will have rapid progression of their disease and will be in ESKD within 5 years of diagnosis (5). Just as differences exist in the prevalence and incidence of NS in different populations, there are also differences in pattern of response to therapy; SSNS is more common in Asian children compared with other ethnicities, and children of Hispanic and African descents are more likely to have SRNS type of NS, suggesting that genetic factors may play a role in both the incidence of NS and pattern of response to therapy (3).

While the most important classification of NS is based on initial response to therapy, other classification schemas exist as well. For example, children with onset of nephrotic syndrome in the first 3 months of life are classified as having congenital nephrotic syndrome (CNS) and it is well known that about $80 \%$ of children with CNS will have genetic NS, with most being therapy resistant (6). While outcomes are heavily dependent on pattern of therapy response, morphologic findings from kidney biopsy also has prognostic significance. For example, more than $80 \%$ of children with minimal change disease (MCD) will have therapy responsive disease and therefore excellent prognosis. On the other hand, most children with focal and segmental glomerulosclerosis (FSGS) will have therapy resistant disease that is characterized by rapid disease progression to ESKD within 5-10 years of diagnosis $(7,8)$.

The etiology of idiopathic childhood nephrotic syndrome has remained elusive for decades. However, secondary causes such as infections (hepatitis B \& C, HIV, etc.), malignancy (leukemia, lymphoma, other $\mathrm{T}$ cell associated cancers), autoimmune disorders (systemic lupus erythematosus, IgA nephropathy, and other immune complex mediated disorders, etc.), and drug associated (non-steroidal anti-inflammatory drugs, certain antibiotics) have been reported (1). More recently advances in genomics and molecular biology have led to identification of over 50 single gene causes of SRNS as well as several genetic risk factors for different morphologic forms of SRNS. However, the contribution of genetic factors to the prevalence and clinical course of SSNS have been harder to define, likely due to a more complex pattern of inheritance and variable phenotypic expression that is characterized by relapse and remission. In this review, we will discuss what is currently known about the genetics of SSNS, provide evidence that there are important genetic drivers of SSNS in different populations, and discuss future approaches to defining the genetic architecture of SSNS.

\section{Pathogenesis}

Massive urinary loss of proteins the size of albumin or greater is the hallmark of nephrotic syndrome (2). Other features of NS include generalized edema, hyperlipidemia, and hypoalbuminemia. In addition, patients with NS are at an increased risk of acute kidney injury, thromboembolic events and infections (9-12).

\section{Proteinuria}

The glomerular filtration barrier (GFB) effectively limits the urine loss of albumin and other higher molecular weight proteins to $<100 \mathrm{mg} / \mathrm{m}^{2}$ per $24 \mathrm{~h}$. This barrier consists of three distinct layers, namely the fenestrated endothelial cells, the glomerular basement membrane, and the specialized visceral epithelial cells, the podocytes. The foot processes of adjacent podocytes interdigitate to form the slit diaphragm. Our recent understanding of the glomerular function now credits the slit diaphragm as a major barrier to the filtration of albumin (13). However, factors responsible for the disruption of the GFB are not completely known and are subject of ongoing investigations.

\section{Role of T and B Cells in the Pathogenesis of Nephrotic Syndrome}

Accumulated evidence points to the role of $\mathrm{T}$ and $\mathrm{B}$ cell disorders in the pathogenesis of steroid sensitive nephrotic syndrome (SSNS). All current therapeutic agents for SSNS act by either depleting $\mathrm{T}$ and $\mathrm{B}$ cell populations or by modulating their functions (14). For example, in children with SSNS characterized by steroid dependent or frequently relapsing course, maintenance of remission is commonly achieved with calcineurin inhibitors and anti-proliferative agents such as mycophenolate mofetil, both agents are known to maintain remission through their effects on $\mathrm{T}$ cell function. $(15,16)$. In addition, NS may also present as paraneoplastic syndrome in some lymphoreticular malignancies. Furthermore, children with NS have been reported to achieve remission following measles infection, a disease that is known to suppress cell-mediated immunity $(17,18)$. Sustained remission of NS following administration of rituximab or ofatumumab, anti-CD20 monoclonal antibodies that deplete B cell population, and the occurrence of NS in some people with light chain gammopathy highlight the additional role of $\mathrm{B}$ cells in the pathogenesis of SSNS (19-21). To date, one of the strongest evidence for the role of adaptive immunity in the pathogenesis of SSNS is the association between SSNS and variants in the gene loci for the human leucocyte class II antigens (22-28). These genes are responsible for the production of surface proteins on immune cells required for antigen presentation.

The exact mechanism of how disorders in the immune systems cause increased permeability of the glomerular filtration barrier is not fully understood. However, dysregulation of different cytokines expressed by activated immune cells like the $\mathrm{T}$ cells have been reported during relapse of NS (29). Also, radical oxygen species are known to cause proteinuria in rats, and activated $\mathrm{T}$ cells cause imbalance in reactive oxygen species (30). Furthermore, some soluble permeability factor such as cardiotrophin-like cytokine 1 factor have been recovered from activated $\mathrm{T}$ cells (31). These circulating permeability factors are thought to alter podocyte structure and functions leading to disruption of the GFB and subsequently proteinuria.

\section{Soluble Circulating Permeability Factors}

Another theory that explains proteinuria in NS is the presence of soluble circulating permeability factors capable of increasing the loss of albumin and higher molecular weight proteins into the urine. This theory considers the normal kidney as 
being in an abnormal milieu (32). Several reported cases in the literature provide support for this theory. Notable among these are recurrence of NS following kidney transplantation in patients with NS especially those with primary focal segmental glomerulosclerosis $(33,34)$. Prevention or remission of proteinuria in these situations following plasmapheresis provides additional support for the role of circulating permeability factors. $(35,36)$ Transient neonatal proteinuria in children born to mothers with NS further strengthens the evidence for the presence of some circulating permeability factors (37). These putative circulating factors are thought to be in the 30-50 $\mathrm{kDa}$ range (38). Their strong affinity to galactose provides the theoretical basis for reports of some efficacy of galactose in the treatment of NS (39).

Some of the putative soluble circulating permeability factors include cardiotrophin-like cytokine 1 factor, soluble urokinaselike plasminogen receptor (suPAR), hemopexin, radical oxygen species, vascular endothelial growth factors, IL-13, IL-18, tumor necrosis factor- $\alpha$, and angiopoetin-like 4 factor (40-42).

These circulating factors, likely acting together, exert their effects on the glomerular filtration barrier to cause proteinuria. For example, hemopexin reduces glomerular sialoproteins and alters the actin cytoskeleton, a major contributor to podocyte structural integrity $(43,44)$.

\section{Podocytes}

The discovery of over 50 single genes causing mostly SRNS highlights the primacy of the role of the podocytes in the pathogenesis of NS. Furthermore, current therapies of NS are known to have non-immune mediated effects on the podocyte, further underscoring its role in the pathogenesis of proteinuria in NS (45-48). The podocyte and slit diaphragm present a major barrier to protein loss in urine. Disturbance in podocyte structure or function is now regarded as the hallmark of NS (49). Hence the recognition of NS as a form of podocytopathy. Although, podocyte dysfunction or alteration in podocyte structure may be a primary event leading to proteinuria, circulating permeability factors, and disorders in $\mathrm{T}$ and $\mathrm{B}$ cell functions are thought to act via perturbation of podocyte function, structure or both (50).

\section{Edema}

Generalized edema is the most common presenting feature of NS. The exact mechanism is not known. Two theories provide explanation for the pathogenesis of edema in NS (51). The most compelling theory is the underfill theory which attributes the edema to the loss of oncotic pressure due to hypoalbuminaemia. The reduction in capillary oncotic pressure leaves the capillary hydrostatic pressure unchallenged, resulting in the net translocation of fluid to the interstitial space. The resulting drop in renal blood flow activates renal angiotensin system and avid conservation of salt and water in the kidney. Support for this theory includes the contracted intravascular volume and high serum renin and aldosterone levels seen in some children with NS $(52,53)$. Improvement in the edema with albumin infusion further supports the underfill theory. In contrast, not every child with NS has contracted intravascular volume and elevated renin or aldosterone level
(53). Furthermore, the prompt disappearance of edema following response to corticosteroids or other immunosuppressants, even with low serum albumin further negates the primacy of the underfill theory. The overfill theory suggests that the cause of edema in NS is a primary increase in the reabsorption of sodium and water in the distal convoluted tubules (54). As suggested by Eddy and Symons, it is likely that the two theories may be at work in the same child to varying degree at different times (2).

\section{Hyperlipidemia}

Hypertriglyceridemia and hypercholesterolemia characterize most cases of NS. The dyslipidemia is due to a combination of increased liver synthesis of albumin and lipoprotein to compensate for urinary loss of albumin, and disturbance in the metabolism of cholesterol (55). Specifically, there is an uptick in the activity of 3-hydroxy-3-methylglutaryl-CoA reductase, involved in the synthesis of cholesterol, and a decrease in activity of enzymes such as lipoprotein lipase, and hepatic lipase, involved in the degradation of lipids (56). Corticosteroids and dietary changes during relapse of NS further contribute to the dyslipidemia associated with NS.

\section{EVIDENCE THAT SSNS HAS STRONG GENETIC COMPONENT}

As mentioned previously, unlike SRNS where over 50 monogenic causes have been identified, single gene causes of SSNS have remained relatively elusive. Nonetheless, several reports point to importance of genetic factors in the risk and pathogenesis of SSNS. First, about 3\% of children with SSNS have a first degree relative with SSNS (57). Second, SSNS is more common in South Asians than Caucasians and other races in both Europe and North America (1, 3, 58). Additionally, risk variants for SSNS in the HLA-class I and II gene loci have been documented in Asian, European, Caucasian, and African-American children $(22-28,59)$. An important first step in adaptive immunity is the presentation of foreign antigens by antigen presenting cells to $\mathrm{T}$ cells. Once activated, the $\mathrm{T}$ cells initiate a cascade of immune reactions that characterize adaptive immunity. Human leucocyte antigens play an important role by acting as receptors for foreign antigens on the surfaces of antigen presenting cells.

\section{Recent Findings From Genetic Studies Mendelian Inheritance}

To date, no single gene has been confirmed to cause SSNS exclusively, however, some children with mutations in SRNS genes such as PLCE1 and NPHS1 have been reported to have steroid responsive disease (Figure 1 and Table 1) $(6,64,65)$. In addition, there are reports of children with NS and mutations in single genes KANK 1 or 2, EXT 1 or FOXP3 who responded to corticosteroids or have minimal change histology (Figure 1 and Table 1) (60-63). A recent study reported a Turkish family with SSNS and loss of function mutation in epithelial membrane protein 2 (EMP2) gene (Figure 1 and Table 1) (60). However, further analysis of a larger cohort of NS patients identified additional patients with both SSNS and SRNS carrying bi-allelic mutations in EMP2, suggesting that mutations in this gene may 


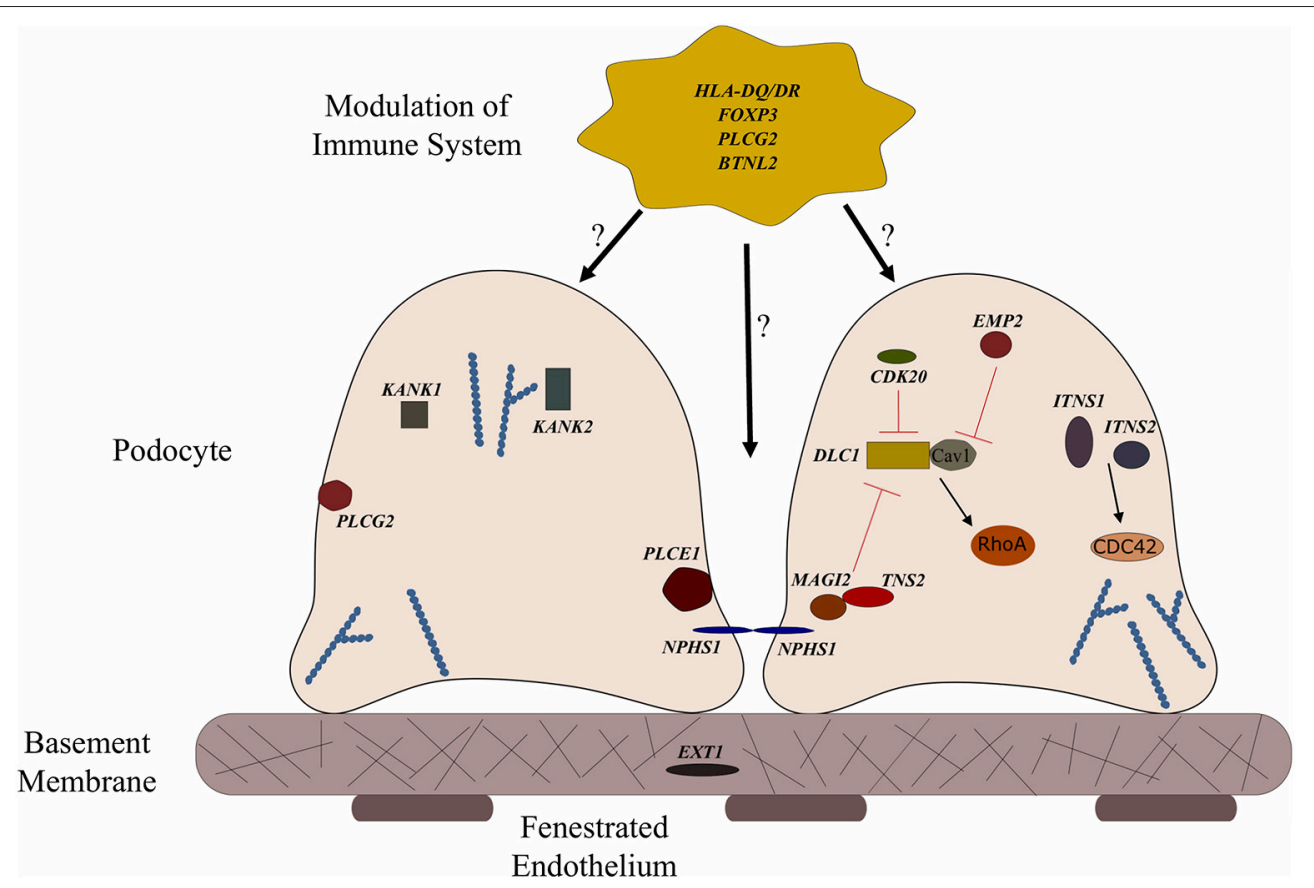

FIGURE 1 | Genes associated with steroid sensitive nephrotic syndrome (SSNS). In the relatively rare cases of monogenic SSNS, the vast majority of genes that have been implicated in SSNS pathology locate to the glomerular filtration barrier and more specifically to the podocytes and slit diaphragm (Table 1). Among them are a key slit diaphragm protein Nephrin encoded by NPHS1 which is known to interact with MAG/2 and TNS2. These two proteins also interact as binding partners and along with $C D K 20$ act to influence podocyte cytoskeletal activity through negative regulation of $D L C 1$ activity (Red lines). DLC1 encodes s a RhoGTPase activating protein for RhoA and its activity can be modulated by the product of EMP2 through inhibition of the DLC1 binding partner Caveolin1 (CAV1). Intersectins 1 and 2 encoded by ITSN1 and ITSN2 act as GEFs for another small RhoGTPase, CDC42. The molecules encoded by KANK1 and KANK2 are also involved in RhoGTPase regulation and are known to affect actin polymerization. PLCE1 and PLCG2 encode proteins that modulate actin cytoskeleton and signaling at the slit diaphragm through calcium regulation. In addition to podocyte expression, PLCG2 is expressed in lymphocytes and it is known to affect immune response signaling. Evidence suggests that most cases of SSNS involve modulation of the immune system, though it is not clear exactly how this immune dysregulation affects the integrity of the glomerular filtration barrier. MHC Class II variants in the HLA-DR/DQ region are likely key components of this altered immune response. Other candidate loci include another MHC class II associated molecule BTNL2, as well as a regulator of T cell activity encoded by FOXP3. EXT1 is expressed in the glomerular basement membrane where it is involved in heparan sulfate biosynthesis.

cause variable disease phenotype. Furthermore, analysis of a large cohort of 131 patients with familial SSNS (59 unrelated families) did not identify pathogenic variants in EMP2 (59).

More recently, a study focused on 17 families with partially treatment sensitive nephrotic syndrome (pTSNS), which includes patients with SSNS, as well as patients with partial response to corticosteroid treatment. Through a combination of homozygosity mapping (HM) and whole exome sequencing (WES) in these families as well as high throughput sequencing of an additional 1000 patients with NS, they identified recessive mutations in six genes (MAGI2, TNS2, DLC1, CDK20, ITSN1, and ITSN2) as novel causes of disease (Figure $\mathbf{1}$ and Table 1) (67). Additionally, this study provided evidence that these six genes act as part of a common Rho GTPase regulatory pathway in podocytes that when disrupted can lead to NS.

In a screen of 400 patients with NS however, Ashraf et al. identified homozygous truncating mutations in MAGI2 as a cause of disease in two patients with SRNS. This has been further confirmed in several additional patients with SRNS in an independent cohort (68). Membrane Associated Guanylate
Kinase Inverted 2 (MAGI2) is a scaffolding protein that regulates podocyte cytoskeletal and slit diaphragm dynamics through interactions with proteins such as nephrin (Figure 1) $(68,69)$. TNS2 encodes tensin2, a focal adhesion molecule that like MAGI2 is known to regulate protein kinase $\mathrm{B}$ ( $\mathrm{PKB} / \mathrm{AKT})$ activity and is vital to proper podocyte cytoskeletal dynamics(Figure 1) $(70,71)$. Whole exome sequencing of a patient with MCD uncovered a homozygous mutations in TNS2 and sequencing of additional patients led to the discovery of five additional homozygous or compound heterozygous pathogenic mutations. WES of a patient diagnosed with membranoproliferative glomerulonephritis (MPGN) identified homozygous missense mutations in a highly conserved amino acid residue of cyclin dependent kinase 20 (CDK20). Ashraf et al. posit that the products of MAGI2 and TNS2 interact and that all three proteins affect RhoGAP activity in podocytes through interactions with, or modulations of DLC1 Rho GTPase-activating protein (Figure 1).

In vitro analysis by Ashraf et al. determined that the Rho GTPase-activating protein encoded by DLC1 regulates RhoA activity, which is essential for maintaining podocyte cytoskeleton 
TABLE 1 | Monogenic causes of SSNS.

\begin{tabular}{|c|c|c|c|c|c|c|}
\hline Gene & Locus & Type of mutation & Protein localization & $\begin{array}{l}\text { Associated with } \\
\text { SRNS }\end{array}$ & Extra renal manifestations & References \\
\hline EMP2 & $16 \mathrm{p} 13$ & Missense, Truncating & Podocyte & Y & No & (60) \\
\hline FOXP3 & Xp11 & Missense & Immune cells & Y & $\begin{array}{l}\text { Immunodeficiency, } \\
\text { Polyendocrinopathy, Enteropathy }\end{array}$ & (62) \\
\hline KANK2 & $19 p 13$ & Missense & Podocyte & Y & No & (63) \\
\hline NPHS1 & $19 q 12$ & Missense & $\begin{array}{l}\text { Podocyte and slit } \\
\text { diaphragm }\end{array}$ & Y & No & (64), (65) \\
\hline PLCE1 & $10 q 23$ & Truncating & $\begin{array}{l}\text { Podocyte and slit } \\
\text { diaphragm }\end{array}$ & Y & No & (66) \\
\hline MAG/2 & $7 q 21$ & Truncating & Podocyte & Y & Neurologic impairment & (67) \\
\hline CDK20 & $9 q 22$ & Missense & Podocyte & $\mathrm{N}$ & No & (67) \\
\hline ITSN1 & $21 q 22$ & Missense & Podocyte & Y & No & (67) \\
\hline ITSN2 & $2 p 23$ & Missense & Podocyte & $\mathrm{N}$ & No & (67) \\
\hline
\end{tabular}

dynamics (Figure 1). High throughput sequencing of the NS cohort revealed four families with recessive mutations in DLC1. Further investigation of additional Rho GTPase modulators revealed mutations in Intersectin1 (ITSN1) and Intersectin2 (ITSN2) as the cause of early onset NS in several families. This included homozygous missense ITSN1 mutations in two siblings in an Arab family and four other compound mutations in two additional families. WES of ITSN2 in five members of a Japanese family with two affected individuals revealed compound heterozygous mutations as a cause of disease which was then confirmed through the discovery of homozygous missense mutations in an additional NS patient. Intersectins are a family of proteins involved in clatherin mediated endocytosis and Ashraf et al. demonstrate that the products of ITSN1 and ITSN2 act as GEFs regulating Cdc42 activity (Figure 1). Dysregulation of these small Rho GTPases has been shown to affect podocyte cytoskeleton dynamics leading to loss of GFB integrity in mice (72-74). The cytoskeletal effects of variants of this pathway are illustrated by reduced cell migration with knockdown of MAGI2 and CDK20, and a loss of podocyte restoration after LPS induced podocyte foot process effacement in ITSN2 homozygous mice. EMP2 is theorized to contribute to this pathway as well through its negative regulation of caveolin-1 expression, whose dysregulation is associated with NS (Figure 1). The interaction with and potential regulation of $D L C 1$ by caveolin1 is lost in SSNS associated DLC1 variants. Dexamethasone is hypothesized to contribute to disease remission by affecting this EMP2-DLC1 pathway and/or by directly affecting Rho GTPase activity. While the results of these studies are extremely valuable to our understanding of NS pathology, the variable steroid response in these patients and a lack of clear connections to the established role of immune dysregulation in SSNS suggests that additional factors may be involved. The genes that have been reported as possible monogenic causes of SSNS are listed in Table 1.

\section{Complex Inheritance}

Though several possible monogenic causes of SSNS have now been reported, Mendelian SSNS is still extremely rare. In addition, these genes are thought to exert their influence on disease primarily through their effects on podocytes. These proposed pathogenic mechanisms fail to explain the apparent contribution of immune dysregulation to SSNS. While corticosteroids and other immunosuppressive therapies may act through podocyte cytoskeletal effects, such as those outlined by Ashraf et al. there have been several SSNS risk loci identified that suggest a more complex immune mediated mechanisms (Table 2). The majority of identified SSNS risk loci are located in the $H L A-D Q$ and $H L A-D R$ region of the human leukocyte antigen (HLA) gene complex encoding MHC class II molecules required for extracellular antigen presentation $(24,25,75-79)$. These $H L A-D Q$ and $H L A-D R$ regions are highly polymorphic, a characteristic that is essential for creating a robust adaptive immune system, however, specific variants have been linked to the development of autoimmune diseases.

Of these HLA genes, variants in the HLA-DR locus were the first to be associated with NS, with variants being linked to disease in a cohort of Japanese children with SSNS (25). However, due to the strong LD between the $D R$ and $D Q$ regions, the specific contributions of the $D R$ and $D Q$ have only recently been examined. In an unbiased exome wide analysis, Gbadegesin et al. identified 4 variants in the HLA-DQA1/HLADQB1 locus associated with SSNS in a South Asian cohort (22). The two HLA-DQA1 variants, rs1129740 and rs1071630, were then replicated in an independent European SSNS cohort. The follow up study revealed that these variants are also associated 
TABLE 2 | SSNS studies implicating MHC || loci.

\begin{tabular}{|c|c|c|c|}
\hline Study population & Cohort size $(n)$ & Gene & References \\
\hline \multirow[t]{2}{*}{ UK Caucasian } & 40 & HLA-DR7 & (75) \\
\hline & & HLA-DQW2 & \\
\hline U.S. Caucasian & 32 & HLA-DQW2 & (76) \\
\hline \multirow{2}{*}{$\begin{array}{l}\text { French and } \\
\text { German }\end{array}$} & 161 & $H L A-D Q B$ & (24) \\
\hline & & $H L A-D Q A$ & \\
\hline Japanese & 24 & HLA-DQB1 & (25) \\
\hline \multirow[t]{2}{*}{ Japanese } & 30 & $H L A-D Q A 1$ & (77) \\
\hline & & HLA-DQB1 & \\
\hline \multirow[t]{2}{*}{ Chinese (Taiwan) } & 59 & HLA-DQB1 & (78) \\
\hline & & $H L A-D R$ & \\
\hline French & 75 & HLA-DQA1 & (79) \\
\hline Dutch & 146 & & \\
\hline British & 335 & & \\
\hline \multirow[t]{2}{*}{ South Indian } & 76 & HLA DRB1 & (23) \\
\hline & & HLA DQB1 & \\
\hline South Asian & 214 & HLA-DQA1 & (22) \\
\hline U.S. white & 100 & & \\
\hline European & 323 & $H L A-D Q A 1$ & (80) \\
\hline African American & 65 & $H L A-D Q A 1$ & (26) \\
\hline $\begin{array}{l}\text { European, North } \\
\text { African, Southeast } \\
\text { Asian }\end{array}$ & 131 & HLA-DQA1 & (59) \\
\hline Japanese & 224 & $H L A-D R$ & (28) \\
\hline Japanese & 216 & $H L A-D Q$ & \\
\hline French caucasian & 132 & $H L A-D R$ & (27) \\
\hline $\begin{array}{l}\text { European } \\
\text { caucasian }\end{array}$ & 133 & $H L A-D Q$ & \\
\hline African & 56 & & \\
\hline Maghrebian & 85 & & \\
\hline
\end{tabular}

with SSNS in African American children (26). This locus has now been confirmed in several other independent studies (Table 3) $(27,28,80)$. HLA imputation in the same cohort of South Asian children revealed HLA-DRB1*07:01, HLA-DQA1*02:01, $H L A-D Q B 1^{*} 02: 01$, and $H L A-D Q A 1^{*} 01: 01$ as the SSNS associated classic HLA alleles (26). These findings seem to suggest that the HLA-DQA1 locus is a cosmopolitan risk allele and it is unlikely to be the explanation for difference in prevalence and severity of SSNS seen in different ethnicities. In depth analysis of HLA-DQA1 at the amino acid level by Adeyemo et al identified strong associations with variations at positions, 76, 56, 69, and -16 (26). The functional implications of these amino acid positions are still unclear but positions 76 and 56 appear to be involved in peptide binding and display potential associations with the development of gluten sensitivity suggesting a possible link between food allergy and SSNS.

Additional support for the involvement of the $H L A-D Q$ region in SSNS came from a study of South Indian patients with NS that reported an association between $H L A-D Q B 1^{*} 02$ and SSNS (23). This was further validated in recent publication identifying the association of the $H L A-D R / D Q$ loci with SSNS in the Japanese population through an unbiased GWAS analysis in two independent cohorts (28). In addition to confirming a previously identified $H L A-D R B 1^{*} 08: 02$ variant as a SSNS risk allele in this population, the study also identified $D Q B 1^{*}$ 03:02 as a risk allele, with the presences of both alleles providing the most significant risk. However, unlike the HLA-DQA1 alleles that appear to be risk factors in all ethnicities studied to date, the HLA-DRB1*08:02 and $D Q B 1^{*}$ 03:02 variants seems to be specific for the Japanese population.

An extensive examination of SSNS associated risk alleles in three independent cohorts of NS patients was recently reported by Debiec et al. (27). This group used trans-ethnic GWAS, followed by meta-analysis and conditional analysis to interrogate a French discovery cohort of 273 children (132 Caucasian, 56 African, and 85 Maghrebian) with SSNS and an independent replication in a cohort of over 100 European (Caucasian) children. In addition to identifying significant associations with the HLA-DQA1 region in the initial GWAS analysis of these cohorts, meta-analysis and conditional analysis revealed two variants in the $H L A-D R / D Q$ region and one variant in the $3^{\prime}$ untranslated region of BTNL2-HCG23-LOC101929163 that were significant across ethnicities. Burden analysis of the two $H L A-D R / D Q$ risk alleles in the multi-ethnic Nephrotic Syndrome Study Network (NEPTUNE) cohort demonstrated an increase in SSNS risk, a decrease in age at onset of disease, and an increase in chances of complete remission associated with patients bearing multiple risk alleles. One of the HLA risk alleles (rs28366266) lies upstream of HLA-DBR1, while the other (rs1063348) is a SNP in the $3^{\prime}$ untranslated region of $H L A-D Q B 1$ that is reported to reduce $H L A-D R B 1, H L A-D R B 5$, and $H L A-D Q B 1$ gene expression in the NEPTUNE cohort. This trans-ethnic analysis suggests that like $H L A-D Q A 1$, variants in $H L A-D Q B$ and $H L A-D R$ regions may also be universal risk factors for SSNS. Furthermore, they demonstrate that these risk alleles may also affect the expression of other genes in the HLA regions, providing a complex pattern of disease inheritance that will require further studies.

\section{Risk Variants Outside of the MHC II Locus}

The replication of associations between $H L A-D R / D Q$ alleles and SSNS in multiple independent cohorts regardless of ethnicity suggests that this region plays a critical role in SSNS pathogenesis. However, these variants fail to explain the phenotypic and ethnic variation observed in SSNS patients, or the lack of renal involvement in the numerous immunologic disorders associated with HLA variants. This suggests the presence of additional genetic factors outside of the HLA region that increase the susceptibility to renal disease. This "trigger, bullet, and target" idea proposes that much like the connection between $H L A$ and PLA2R1 gene variants in adult membranous nephropathy, HLA variants in SSNS act as the trigger for unknown factors that connect immunologic dysfunction to renal disease (79). While the lack of strong SSNS genetic associations outside of HLA regions indicate these unknown factors may be diverse even within ethnicities, recent reports have identified rare variants in two SSNS candidate genes outside of the classical HLA region, PLCG2, and BTNL2 that may contribute to disease $(22,27)$.

In the same cohort of South Asian NS patients used to identify associations between classical $H L A-D Q A 1$ variants and 
TABLE 3 | HLA SNPS and classic alleles identified in SSNS cohorts.

\begin{tabular}{|c|c|c|c|c|c|}
\hline SNP & $\begin{array}{l}\text { Adeyemo } \\
\text { et al. (26) }\end{array}$ & $\begin{array}{l}\text { Jia } \\
\text { et al. (28) }\end{array}$ & $\begin{array}{l}\text { Debiec } \\
\text { et al. (27) }\end{array}$ & $\begin{array}{l}\text { Sekula } \\
\text { et al. (80) }\end{array}$ & $\begin{array}{l}\text { Dorval } \\
\text { et al. (59) }\end{array}$ \\
\hline \multicolumn{6}{|l|}{ HLA-DQA1 } \\
\hline rs1129740 & $x$ & $X^{*}$ & $X^{*}$ & - & $x$ \\
\hline rs1071630 & $x$ & $X^{*}$ & $X^{*}$ & - & $x$ \\
\hline rs9272729 & - & - & - & $x$ & - \\
\hline \multicolumn{6}{|l|}{ HLA-DQB1 } \\
\hline rs4642516 & - & $x$ & - & - & - \\
\hline rs3134996 & - & $x$ & - & - & - \\
\hline rs1063348 & - & - & $x$ & - & - \\
\hline \multicolumn{6}{|l|}{ HLA-DRB1 } \\
\hline rs28366266 & - & - & $x$ & - & - \\
\hline HLA Alleles & $\begin{array}{l}\text { Adeyemo } \\
\text { et al. (26) }\end{array}$ & $\begin{array}{l}\text { Jia } \\
\text { et al. (28) }\end{array}$ & $\begin{array}{l}\text { Debiec } \\
\text { et al. (27) }\end{array}$ & $\begin{array}{l}\text { Sekula } \\
\text { et al. (80) }\end{array}$ & - \\
\hline $\begin{array}{l}\text { HLA- } \\
\text { DQA1*0101 }\end{array}$ & $x$ & - & - & - & - \\
\hline $\begin{array}{l}\text { HLA- } \\
D Q A 1^{*} 0201\end{array}$ & $x$ & - & $x$ & - & - \\
\hline $\begin{array}{l}\text { HLA- } \\
D Q A 1^{*} 0501\end{array}$ & - & - & - & $x$ & - \\
\hline $\begin{array}{l}\text { HLA- } \\
\text { DQB1*0201 }\end{array}$ & $x$ & - & - & $x$ & - \\
\hline $\begin{array}{l}\text { HLA- } \\
D Q B 1^{\star} 0302\end{array}$ & - & $x$ & - & - & - \\
\hline $\begin{array}{l}\text { HLA- } \\
D Q B 1^{*} 0602\end{array}$ & - & $x$ & - & - & - \\
\hline $\begin{array}{l}\text { HLA- } \\
D Q B 1^{*} 0604\end{array}$ & - & $x$ & - & - & - \\
\hline $\begin{array}{l}\text { HLA- } \\
\text { DRB1*0202 }\end{array}$ & - & $x$ & - & - & - \\
\hline $\begin{array}{l}\text { HLA- } \\
D R B 1^{\star} 0301\end{array}$ & - & - & - & $x$ & - \\
\hline $\begin{array}{l}\text { HLA- } \\
\text { DRB } 1^{*} 0701\end{array}$ & $x$ & - & $x$ & - & - \\
\hline $\begin{array}{l}\text { HLA- } \\
\text { DRB } 1^{\star} 0802\end{array}$ & - & $x$ & - & - & - \\
\hline $\begin{array}{l}\text { HLA- } \\
D R B 1^{*} 1302\end{array}$ & & $x$ & - & - & - \\
\hline
\end{tabular}

$X$, significant association; * $S N P$ in $L D$.

SSNS, Gbadegesin et al. performed rare variant gene setbased analysis to identify other candidate risk loci. The best signal from this analysis was found in PLCG2 $(P=7.8 \times$ $10^{-5}$ ). Phospholipase C gamma-2 (PLCG2) encodes a critical signaling enzyme that is required for the production of inositol triphosphate (IP3) and diacylglycerol (DAG) in response to growth and immune system receptor activation. Mutations in PLCG2 affect lymphocyte signaling and differentiation with hypermorphic variants associated with autoimmunity disorders in humans and glomerulonephritis in mice (81-83). A recent report has identified compound missense variants in PLCG2 as a cause of disease in a set of twins with SSNS (84). They demonstrate that these rare variants are hypermorphic, resulting in an increase in B cell calcium flux, which is associated with an
TABLE 4 | Candidate gene polymorphism studies in childhood SSNS.

\begin{tabular}{|c|c|c|c|c|}
\hline Gene & Association & $\begin{array}{c}\text { Total NS } \\
\text { cohort (SSNS) }\end{array}$ & Ethnicity & References \\
\hline \multirow[t]{8}{*}{$\begin{array}{l}A B C B 1 \\
\text { (MDR1) }\end{array}$} & $\begin{array}{l}\text { Steroid } \\
\text { response }\end{array}$ & $120(80)$ & Egyptian & (95) \\
\hline & $\begin{array}{l}\text { Steroid } \\
\text { response }\end{array}$ & 170 (69) & Korean & (96) \\
\hline & $\begin{array}{l}\text { Steroid } \\
\text { response }\end{array}$ & $150(50)$ & Egyptian & (97) \\
\hline & $\begin{array}{l}\text { NS/Steroid } \\
\text { response }\end{array}$ & 63 & Tunisian & (98) \\
\hline & $\begin{array}{l}\text { Steroid } \\
\text { response }\end{array}$ & $74(58)$ & Chinese & (99) \\
\hline & $\begin{array}{l}\text { Steroid } \\
\text { response }\end{array}$ & $216(137)$ & $\begin{array}{l}\text { North } \\
\text { Indian }\end{array}$ & (100) \\
\hline & $\begin{array}{l}\text { Steroid } \\
\text { response }\end{array}$ & $138(92)$ & Egyptian & (101) \\
\hline & $\begin{array}{l}\text { Age/Steroid } \\
\text { response }\end{array}$ & $46(33)$ & Slovakian & (102) \\
\hline $\begin{array}{l}\text { GR } \\
\text { (NR3C1) }\end{array}$ & $\begin{array}{l}\text { Steroid } \\
\text { response }\end{array}$ & 154 & Chinese & (103) \\
\hline$T N F \alpha$ & $\begin{array}{l}\text { Steroid } \\
\text { response }\end{array}$ & $150(100)$ & Egyptian & (104) \\
\hline IL-4 & $\begin{array}{l}\text { Frequent } \\
\text { relapse }\end{array}$ & $55(55)$ & Chinese & (105) \\
\hline \multirow[t]{2}{*}{$A C E$} & $\begin{array}{l}\text { NS/Frequent } \\
\text { relapse }\end{array}$ & 227 (144) & Turkish & (106) \\
\hline & $\begin{array}{l}\text { Steroid } \\
\text { response }\end{array}$ & $125(90)$ & Indian & (107) \\
\hline IL12B & $\begin{array}{l}\text { Steroid } \\
\text { dependence }\end{array}$ & $79(79)$ & German & (108) \\
\hline
\end{tabular}

increased immune response. While the contributions of PLCG2 to adaptive immunity have been extensively studied, the effect of these variants on GFB integrity have not been examined, despite its robust expression in the glomerulus (85). With a known role in intracellular calcium regulation, it is plausible that PLCG2 variants may directly contribute to podocyte injury, especially with the discovery of variants in a related PLC enzyme, PLCE1, as a cause of NS with variable therapy response (Figure 1) (66). Recently, expression quantitative loci analysis of NS patients in the Nephrotic Syndrome Study Network (NEPTUNE) identified PLCG2 as one of the most highly regulated genes in the glomerulus, suggesting a possible role for PLCG2 modulation in NS (85). Further studies will be required to determine if variants in PLCG2 are truly capable of acting as a monogenic cause of disease or if it serves as a contributing genetic factor that may or may not be specific for some ethnicities.

In the GWAS analysis of SSNS patients recently reported by Debiec et al., a missense variant in exon 3 of butyrophilin like2 (BTNL2) was found to be the lead SNP in the African patients in their French discovery cohort. Subsequent transethnic metaanalysis in all four SSNS cohorts with conditioning for two HLA loci SNPs (rs1063348 and rs28366266) revealed a significant SNP located in close proximity to the $3^{\prime}$ UTR of BTNL2, providing additional support for a potential role in SSNS pathogenesis. 
BTNL2 encodes a MHC Class II associated transmembrane protein that is involved in immune response regulation. Like PLCG2, variants in BTNL2 are associated with several disorders involving elevated auto-immune responses due to its role as a negative regulator of $\mathrm{T}$ cell proliferation and cytokine release $(79,86,87)$. The precise connections between BTNL2 variants and the loss of GFB integrity is unclear but the increased release of inflammatory cytokines due to a loss of BTNL2 activity may serve as an additional immunologic insult capable of disrupting GFB integrity in the presence of additional podocyte related gene defects (Figure 1).

\section{Candidate Genes}

There are also several reports of genetic polymorphisms in genes such as CYP3A4, CYP3A5, ABCB1, and GR that can affect response to immunosuppressants in children with NS (88-94). Clearly, this additional variable will complicate treatment strategies for NS and could account for some of the variable response to immunosuppression in patients with both SSNS and SRNS. Aside from the obvious connection between glucocorticoid receptor (GR) function and corticosteroid response, the products of $C Y P 3 A 4, C Y P 3 A 5$, and $A B C B 1$ are required for metabolism of calcineurin inhibitors like tacrolimus, providing biologic relevance to these variant associations. However, while associations have been identified between variants in $G R$ and $A B C B 1$ and steroid response in patients with NS, none of these genes have been found to be associated with increased incidence of SSNS (Table 4) (95-103). Additional associations between biologically relevant molecules and steroid response or relapse rates in NS patients including variants in genes encoding important signaling molecules such as Tumor necrosis factor alpha (TNF $\alpha$ ), Angiotensin-converting enzyme (ACE), Interleukin 4 (IL4), and Interleukin 12 (IL12B promoter) have been reported (Table 4) (104-108). However, unlike the studies of HLA gene associations, these SSNS candidate gene studies have often lacked unbiased genome or exome wide analysis and most of the findings have not been replicated by other investigators in either gene/variant specific or unbiased genome wide studies. While it is plausible that SNPs in biologically related molecules can affect patients responses to immunosuppression, further large scale unbiased studies will be required to determine the role of these candidate genes/variants in the pathogenesis of SSNS. The candidate variants/genes identified to date in studies of childhood SSNS and their associations with disease are listed in Table 4.

\section{FUTURE DIRECTIONS}

Despite significant advances in our knowledge of the genetic mechanisms underlying the pathogenesis of NS, several gray areas still remain. The genetic diversity of MHCII loci in different populations suggests a central role for adaptive immunity in the development of SSNS and immune-mediated diseases. Variants in the HLA-DQA1, HLA-DQB1, and HLA$D R B 1$ appear to be risk factors for SSNS regardless of ethnicity. This universal significance and the high prevalence of variants

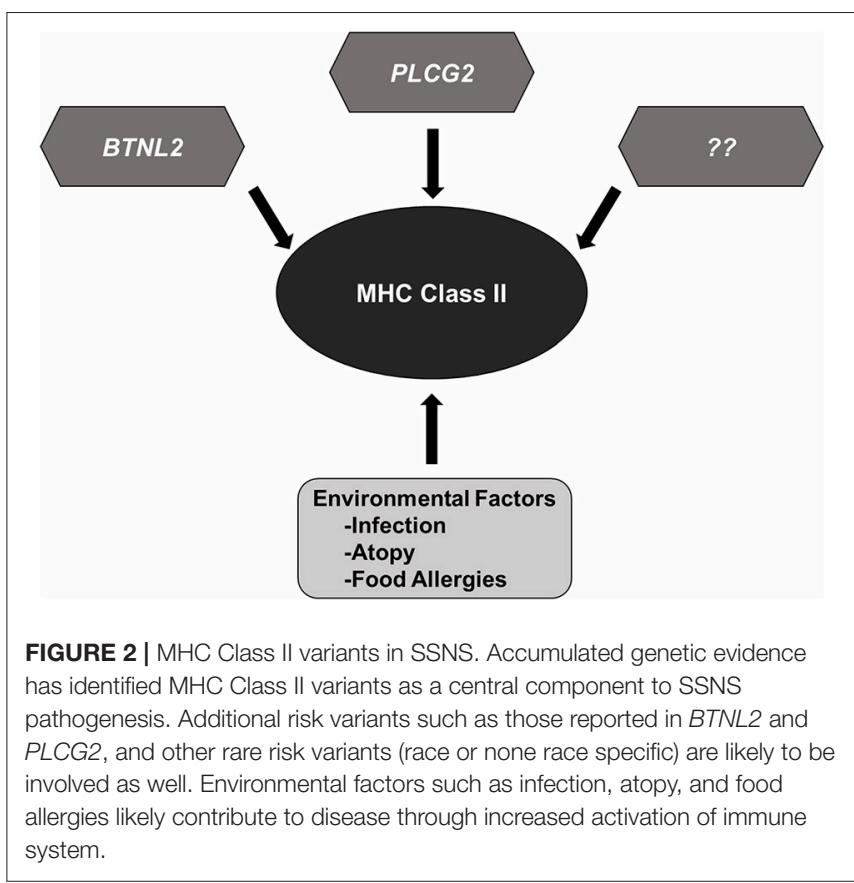

in these genes despite low incidence of SSNS in the general population suggests that most MHCII variants require the presence of additional genetic and non-genetic factors to drive the development of SSNS, and possibly explain the variability in disease prevalence and severity between different ethnicities (Figure 2). Some of these factors include environmental influences such as infections, atopy, and food allergies that can cause dysregulation of the immune system. However, the precise connections between immunologic dysregulation and podocyte dysfunction remain unclear. Understanding how rare genetic variants such as those in PLCG2 and BTNL2, act in concert with the more common MHCII variants to predispose NS patients to disease most likely holds the key to a better understanding of disease pathogenesis and identification of specific and non-toxic therapeutic targets. Such studies will require large patient cohort and therefore robust international collaborations.

Within SSNS, it is possible that there are at least two distinct groups based on disease mechanisms. The first group will be patients with complex disease mechanisms due to interplay of environmental factors and disease risk variants in the $\mathrm{MHC}$ II and non-MHC loci. This group most likely represents the majority of children with SSNS. On the other hand it is possible that there is another very small group with disease driven primarily by dysregulation of pathways that are responsible for maintaining normal function and structure of the podocyte. Most of the children with monogenic SSNS will probably belong to this latter group.

While SSNS and SRNS are generally considered to be distinct entities with diverging pathologies, recent evidence suggest that these conditions exist as endpoints on a spectrum of NS disease. The response to therapy appears to be determined primarily by the degree to which podocyte viability is directly affected by 


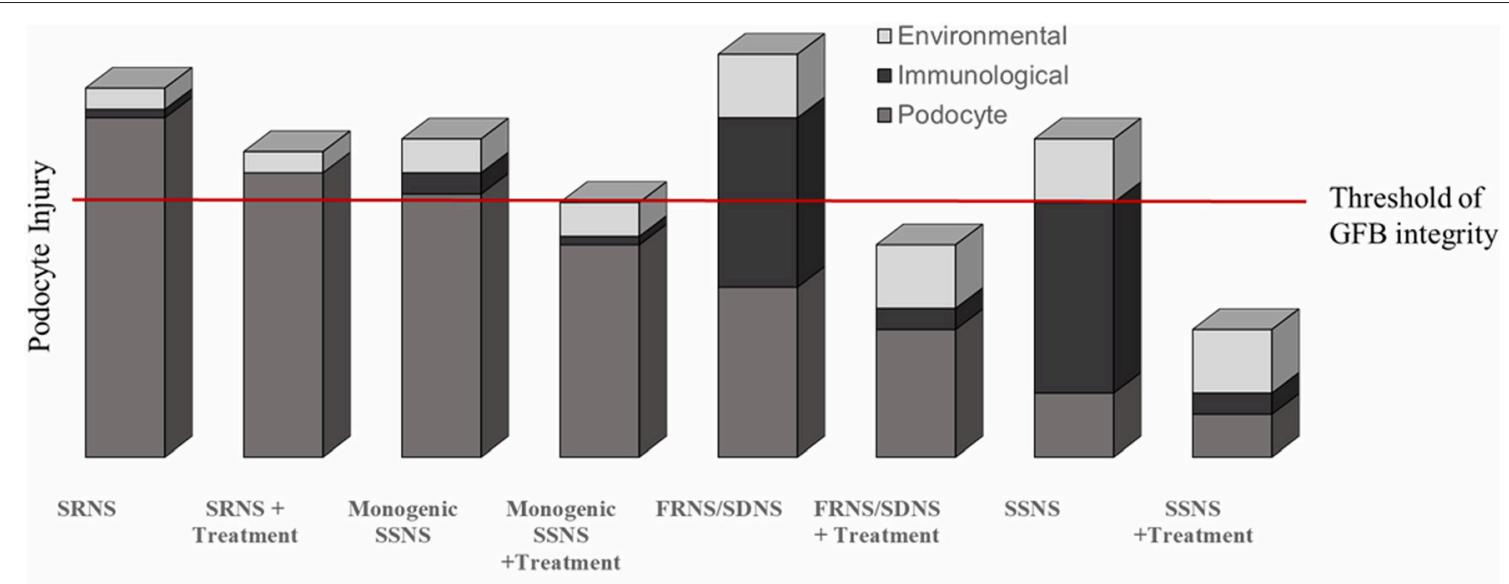

Genetic Podocyte Injury

Response to Steroids

FIGURE 3 | Genetic and environmental contributions to NS. Evidence suggests that SSNS results from combination of immunological and environmental insults to podocyte in a genetic background that is susceptible to podocyte injury and that there is likely a negative correlation between therapy response in NS patients and the degree of genetic podocyte injury. In a simplified view of Nephrotic Syndrome, there is likely a threshold of podocyte injury at which glomerular filtration barrier integrity is lost (red line). In SRNS, the loss of GFB integrity results primarily from genetic insults to podocyte viability that is too profound to overcome with any beneficial cytoskeletal effects of immunosuppressants. Monogenic cases of SSNS likely have less genetic podocyte injury than SRNS, such that immunosuppressive therapy is largely successful at restoring GFB integrity but the overall podocyte viability is still damaged enough to allow environmental factors to influence remission status. More common and polygenic SSNS have a larger contribution of immunological insults to podocyte, which results in a more robust response to immunomodulatory therapy. Frequent relapsers likely have a higher level of baseline podocyte injury than infrequent relapsers.

deleterious genetic variations (Figure 3). In a highly simplified view, it is likely that there is a threshold of podocyte injury needed for loss of GFB integrity and development of NS. This podocyte injury may be a direct result of genetic variants or may occur as an accumulated effect of genetic, environmental, and immunological insults. The majority of variants associated with SRNS cause direct podocyte injury that is too far above the threshold of GFB integrity to allow for disease remission following use of immune modulating therapies (Figure 3). Monogenic SSNS and partially steroid responsive NS variants on the other hand, likely result from variants that directly affect podocyte health to a lesser degree than most SRNS associated variants. Disease phenotypes in these patients can be partially ameliorated by the beneficial podocyte cytoskeletal effects of immunomodulatory medications (Figure 3). The more common and complex forms of SSNS are likely to be driven primarily by variants in components of the immune system such as HLA genes with large effects and contributions from variants in genes outside of the HLA region that may be race specific (109). Many of these contributing variants likely affect podocyte viability, leaving the patients susceptible to immunologic and environmental insults to podocyte health. Individuals with frequently relapsing or steroid dependent NS likely have higher cumulative podocyte injury levels than those with SSNS who are non-frequent relapsers (Figure 3). This high baseline level of injury allows for rapid progression from remission to relapse. The development of resistance to immunotherapy in some SSNS patients is likely the result of the continued environmental and immunological insults to podocyte health driving injury beyond a point where normal GFB function can be restored.

If this general hypothesis is correct and cumulative podocyte injury is the driving force behind all forms of NS regardless of therapy response, then the key to treating nephrotic syndrome more effectively lies in identifying ways to restore podocyte viability. While targeting podocyte injury in SRNS patients may appear obvious, this strategy should be extended to SSNS patients as well. By focusing on podocyte health, we may be able to reduce the chances of relapse or steroid dependency in SSNS patients and avoid the harmful side-effects of immunosuppression, even if only by lowering the effective dose. This strategy will rely on our ability (1) to determine the precise mechanisms by which known immunological variants affect podocyte viability, (2) to identify novel variants that contribute to NS pathology through continued genetic analysis of large patient cohorts, and (3) to determine the key signaling pathways in podocytes onto which multiple pathogenic variants converge. Identification of these common molecular pathways is a critical step toward identification of novel effective therapeutic targets. A possible preliminary approach in this effort would be to examine changes in gene transcription during relapse and remission of SSNS. Through the knowledge acquired from studies such as 
these, we can start to identify potential druggable therapeutic targets.

\section{CONCLUSION}

In conclusion, evidence from published studies suggest that the vast majority of SSNS cases are likely due to a complex interaction between variations in adaptive immunity, factors innate to the kidney, environmental factors and other population-specific rare genetic variants. A first step to understanding this complexity will be identification of rare genetic variants that are acting in concert with adaptive immunity to predispose patients to SSNS. Such a study can only be accomplished by large scale international collaborative studies. In addition, integration of data from such studies with epidemiologic studies and other omics study will ultimately lead to better understanding of disease mechanisms and identification of more effective and non-toxic therapies for SSNS.

\section{REFERENCES}

1. Noone DG, Iijima K, Parekh R. Idiopathic nephrotic syndrome in children. Lancet (2018) 392:61-74. doi: 10.1016/S0140-6736(18)30536-1

2. Eddy AA, Symons JM. Nephrotic syndrome in childhood. Lancet (2003) 362:629-39. doi: 10.1016/S0140-6736(03)14184-0

3. Banh THM, Hussain-Shamsy N, Patel V, Vasilevska-Ristovska J, Borges $\mathrm{K}$, Sibbald $\mathrm{C}$, et al. Ethnic differences in incidence and outcomes of childhood nephrotic syndrome. Clin J Am Soc Nephrol. (2016) 11:1760-8. doi: 10.2215/CJN.00380116

4. Primary nephrotic syndrome in children: clinical significance of histopathologic variants of minimal change and of diffuse mesangial hypercellularity. Kidney Int. (1981) 20:765-71. doi: 10.1038/ki.1981.209

5. Trautmann A, Schnaidt S, Lipska-Zietkiewicz BS, Bodria M, Ozaltin F, Emma F, et al. Long-term outcome of steroid-resistant nephrotic syndrome in children. J Am Soc Nephrol. (2017) 28:3055-65. doi: 10.1681/ASN.2016101121

6. Hinkes BG, Mucha B, Vlangos CN, Gbadegesin R, Liu J, Hasselbacher K, et al. Nephrotic syndrome in the first year of life: two thirds of cases are caused by mutations in 4 genes (NPHS1, NPHS2, WT1, and LAMB2). Pediatrics (2007) 119:e907-19. doi: 10.1542/peds.2006-2164

7. Cattran DC, Rao P. Long-term outcome in children and adults with classic focal segmental glomerulosclerosis. Am J Kidney Dis. (1998) 32:72-9. doi: 10.1053/ajkd.1998.v32.pm9669427

8. Mekahli D, Liutkus A, Ranchin B, Yu A, Bessenay L, Girardin E, et al. Long-term outcome of idiopathic steroid-resistant nephrotic syndrome: a multicenter study. Pediatr Nephrol. (2009) 24:1525-32. doi: 10.1007/s00467-009-1138-5

9. Rheault MN, Zhang L, Selewski DT, Kallash M, Tran CL, Seamon M, et al. AKI in children hospitalized with nephrotic syndrome. Clin J Am Soc Nephrol. (2015) 10:2110-8. doi: 10.2215/CJN.06620615

10. Lilova MI, Velkovski IG, Topalov IB. Thromboembolic complications in children with nephrotic syndrome in Bulgaria 1974-1996. Pediatr Nephrol. (2000) 15:74-8. doi: 10.1007/s004679900253

11. McIntyre P, Craig JC. Prevention of serious bacterial infection in children with nephrotic syndrome. J Paediatr Child Health (1998) 34:314-7. doi: 10.1046/j.1440-1754.1998.00232.x

12. Minimal change nephrotic syndrome in children: deaths during the first 5 to 15 years' observation. Report of the International Study of Kidney Disease in Children. Pediatrics (1984) 73:497-501.

13. Tryggvason K, Wartiovaara J. Molecular basis of glomerular permselectivity. Curr Opin Nephrol Hypertens (2001) 10:543-9. doi: 10.1097/00041552-200107000-00009

\section{AUTHOR CONTRIBUTIONS}

All authors contributed to the writing of this manuscript. BL created figures and tables. BL and RG edited the manuscript.

\section{FUNDING}

RG is supported by the National Institutes of Health and National Institute of Diabetes and Digestive and Kidney Disease (NIDDK) grant 5R01DK098135 and 5R01DK094987. BL is supported by the National Institutes of Health grant T32-DK007731-22.

\section{ACKNOWLEDGMENTS}

We would like to thank the personnel of the Molecular Genomics core at the Duke Molecular Physiology Institute (DMPI) and all families involved in the Duke Genetics of Nephrotic Syndrome project.

14. Colucci M, Corpetti G, Emma F, Vivarelli M. Immunology of idiopathic nephrotic syndrome. Pediatr Nephrol. (2018) 33:573-84. doi: 10.1007/s00467-017-3677-5

15. Shen X, Jiang H, Ying M, Xie Z, Li X, Wang H, et al. Calcineurin inhibitors cyclosporin $\mathrm{A}$ and tacrolimus protect against podocyte injury induced by puromycin aminonucleoside in rodent models. Scientific Rep. (2016) 6:7. doi: $10.1038 /$ srep32087

16. Lv W, Lou J, Zhang Y, Lian P, Qi D, Wang J. Mycophenolate mofetil inhibits hypertrophy and apoptosis of podocyte in vivo and in vitro. Int J Clin Exp Med. (2015) 8: 19781-90.

17. Lin CY, Hsu HC. Histopathological and immunological studies in spontaneous remission of nephrotic syndrome after intercurrent measles infection. Nephron (1986) 42:110-5. doi: 10.1159/000183647

18. Lien YHH, Lai LW. Pathogenesis diagnosis and management of paraneoplastic glomerulonephritis. Nat Rev Nephrol. (2011) 7:85-95. doi: 10.1038/nrneph.2010.171

19. Sinha A, Bhatia D, Gulati A, Rawat M, Dinda AK, Hari P, et al. Efficacy and safety of rituximab in children with difficult-to-treat nephrotic syndrome. Nephrol Dial Transplant. (2015) 30:96-106. doi: 10.1093/ndt/gfu267

20. Nasr SH, Satoskar A, Markowitz GS, Valeri AM, Appel GB, Stokes MB, et al. Proliferative glomerulonephritis with monoclonal IgG deposits. JASN (2009) 20:2055-64. doi: 10.1681/ASN.2009010110

21. Wang CS, Liverman RS, Garro R, George RP, Glumova A, Karp A, et al. Ofatumumab for the treatment of childhood nephrotic syndrome. Pediatr Nephrol. (2017) 32:835-41. doi: 10.1007/s00467-017-3621-8

22. Gbadegesin RA, Adeyemo A, Webb NJA, Greenbaum LA, Abeyagunawardena A, Thalgahagoda S, et al. HLA-DQA1 and PLCG2 are candidate risk loci for childhood-onset steroid-sensitive nephrotic syndrome. J Am Soc Nephrol. (2015) 26:1701-10. doi: 10.1681/ASN.2014030247

23. Ramanathan ASK, Senguttuvan $\mathrm{P}$, Chinniah $\mathrm{R}$, Vijayan $\mathrm{M}$, Thirunavukkarasu M, Raju K, et al. Association of HLA-DR/DQ alleles and haplotypes with nephrotic syndrome. Nephrology (2016) 21:745-52. doi: $10.1111 /$ nep.12669

24. Konrad M, Mytilineos J, Bouissou F, Scherer S, Gulli MP, Meissner I, et al. HLA class II associations with idiopathic nephrotic syndrome in children. Tissue Antigens (1994) 43:275-80. doi: 10.1111/j.1399-0039.1994.tb02340.x

25. Abe KK, Michinaga I, Hiratsuka T, Ogahara S, Naito S, Arakawa K, et al. Association of $\operatorname{DQB1}^{*}(0302)$ alloantigens in Japanese pediatric patients with steroid-sensitive nephrotic syndrome. Nephron (1995) 70:2834. doi: 10.1159/000188540

26. Adeyemo A, Esezobor C, Solarin A, Abeyagunawardena A, Kari JA, El Desoky S, et al. HLA-DQA1 and APOL1 as risk loci for childhood-onset 
steroid-sensitive and steroid-resistant nephrotic syndrome. Am J Kidney Dis. (2018) 71:399-406. doi: 10.1053/j.ajkd.2017.10.013

27. Debiec H, Dossier C, Letouzé E, Gillies CE, Vivarelli M, Putler RK, et al. Transethnic, genome-wide analysis reveals immune-related risk alleles and phenotypic correlates in pediatric steroid-sensitive nephrotic syndrome. $J$ Am Soc Nephrol. (2018) 29:2000-13. doi: 10.1681/ASN.2017111185

28. Jia X, Horinouchi T, Hitomi Y, Shono A, Khor S-S, Omae Y, et al. Strong association of the HLA-DR/DQ locus with childhood steroid-sensitive nephrotic syndrome in the japanese population. J Am Soc Nephrol. (2018) 29:2189-99. doi: 10.1681/ASN.2017080859

29. van den Berg JG, Weening JJ. Role of the immune system in the pathogenesis of idiopathic nephrotic syndrome. Clin Sci. (2004) 107:125-36. doi: $10.1042 / C S 20040095$

30. Bertelli R, Trivelli A, Magnasco A, Cioni M, Bodria M, Carrea A, et al. Failure of regulation results in an amplified oxidation burst by neutrophils in children with primary nephrotic syndrome. Clin Exp Immunol. (2010) 161:151-8. doi: 10.1111/j.1365-2249.2010.04160.x

31. Senaldi G, Stolina M, Guo J, Faggioni R, McCabe S, Kaufman SA, et al. Regulatory effects of novel neurotrophin-1/b cell-stimulating factor3 (cardiotrophin-like cytokine) on B cell function. J Immunol. (2002) 168:5690-8. doi: 10.4049/jimmunol.168.11.5690

32. Coward RJM, Foster RR, Patton D, Ni L, Lennon R, Bates DO, et al. Nephrotic plasma alters slit diaphragm-dependent signaling and translocates nephrin, Podocin, and CD2 associated protein in cultured human podocytes. J Am Soc Nephrol. (2005) 16:629-37. doi: 10.1681/ASN.2004030172

33. Briganti EM, Russ GR, McNeil JJ, Atkins RC, Chadban SJ. Risk of renal allograft loss from recurrent glomerulonephritis. N Engl J Med. (2002) 347:103-9. doi: 10.1056/NEJMoa013036

34. Cañas L, López D, Pérez JF, Bancu I, Juega J, Ariza A, et al. Recurrent glomerulonephritis in renal transplantation: experience in our renal transplantation center. Transplant Proc. (2015) 47:2354-6. doi: $10.1016 /$ j.transproceed.2015.08.024

35. Ohta T, Kawaguchi H, Hattori M, Komatsu Y, Akioka Y, Nagata M, et al. Effect of pre-and postoperative plasmapheresis on posttransplant recurrence of focal segmental glomerulosclerosis in children. Transplantation (2001) 71:628-33. doi: 10.1097/00007890-200103150-00008

36. Gohh RY, Yango AF, Morrissey PE, Monaco AP, Gautam A, Sharma $\mathrm{M}$, et al. Preemptive plasmapheresis and recurrence of FSGS in highrisk renal transplant recipients. Am J Transplant. (2005) 5:2907-12. doi: 10.1111/j.1600-6143.2005.01112.x

37. Kemper MJ, Wolf G, Müller-Wiefel DE. Transmission of glomerular permeability factor from a mother to her child. N Engl J Med. (2001) 344:386-7. doi: 10.1056/NEJM200102013440517

38. Savin VJ, Sharma R, Sharma M, McCarthy ET, Swan SK, Ellis E, et al. Circulating factor associated with increased glomerular permeability to albumin in recurrent focal segmental glomerulosclerosis. N Engl J Med. (1996) 334:878-83. doi: 10.1056/NEJM199604043341402

39. De Smet E, Rioux J-P, Ammann H, Déziel C, Quérin S. FSGS permeability factor-associated nephrotic syndrome: remission after oral galactose therapy. Nephrol Dial Transplant. (2009) 24:2938-40. doi: 10.1093/ndt/ gfp278

40. Clement LC, Avila-Casado C, Macé C, Soria E, Bakker WW, Kersten $\mathrm{S}$, et al. Podocyte secreted Angiopoietin-like 4 mediates proteinuria in glucocorticoid sensitive nephrotic syndrome. Nat Med. (2011) 17:117-22. doi: $10.1038 / \mathrm{nm} .2261$

41. McCarthy ET, Sharma M, Savin VJ. Circulating permeability factors in idiopathic nephrotic syndrome and focal segmental glomerulosclerosis. Clin J Am Soc Nephrol. (2010) 5:2115-21. doi: 10.2215/CJN.03800609

42. Davin J-C. The glomerular permeability factors in idiopathic nephrotic syndrome. Pediatr Nephrol. (2016) 31:207-15. doi: 10.1007/s00467-015-3082-x

43. Lennon R, Singh A, Welsh GI, Coward RJ, Satchell S, Ni L, et al. Hemopexin induces nephrin-dependent reorganization of the actin cytoskeleton in podocytes. J Am Soc Nephrol. (2008) 19:2140-9. doi: 10.1681/ASN.2007080940

44. Bakker WW, Borghuis T, Harmsen MC, van den Berg A, Kema IP, Niezen KE, et al. Protease activity of plasma hemopexin. Kidney Int. (2005) 68:603-10. doi: $10.1111 /$ j.1523-1755.2005.00438.x
45. Stefanidis CJ, Querfeld U. The podocyte as a target: cyclosporin A in the management of the nephrotic syndrome caused by WT1 mutations. Eur J Pediatr. (2011) 170:1377-83. doi: 10.1007/s00431-011-1397-6

46. Jiang L, Dasgupta I, Hurcombe JA, Colyer HF, Mathieson PW, Welsh GI. Levamisole in steroid-sensitive nephrotic syndrome: usefulness in adult patients and laboratory insights into mechanisms of action via direct action on the kidney podocyte. Clin Sci. (2015) 128:883-93. doi: 10.1042/CS20140749

47. Müller-Deile J, Schiffer M. Podocyte directed therapy of nephrotic syndrome-can we bring the inside out? Pediatr Nephrol. (2016) 31:393-405. doi: 10.1007/s00467-015-3116-4

48. Fornoni A, Sageshima J, Wei C, Merscher-Gomez S, Aguillon-Prada $\mathrm{R}$, Jauregui AN, et al. Rituximab targets podocytes in recurrent focal segmental glomerulosclerosis. Sci Transl Med. (2011) 3:85ra46. doi: $10.1126 /$ scitranslmed.3002231

49. Barisoni L, Schnaper HW, Kopp JB. A proposed taxonomy for the podocytopathies: a reassessment of the primary nephrotic diseases. Clin J Am Soc Nephrol. (2007) 2:529-42. doi: 10.2215/CJN.04121206

50. Wei C, Möller CC, Altintas MM, Li J, Schwarz K, Zacchigna S, et al. Modification of kidney barrier function by the urokinase receptor. Nat Med. (2008) 14:55-63. doi: 10.1038/nm1696

51. Bockenhauer D. Over- or underfill: not all nephrotic states are created equal. Pediatr Nephrol. (2013) 28:1153-6. doi: 10.1007/s00467-013-2435-6

52. Usberti M, Federico S, Meccariello S, Cianciaruso B, Balletta M, Pecoraro $\mathrm{C}$, et al. Role of plasma vasopressin in the impairment of water excretion in nephrotic syndrome. Kidney Int. (1984) 25:422-9. doi: 10.1038/ki.1984.34

53. Van de Walle JG, Donckerwolcke RA, Greidanus TB, Joles JA, Koomans HA. Renal sodium handling in children with nephrotic relapse: relation to hypovolaemic symptoms. Nephrol Dial Transplant. (1996) 11:2202-8. doi: 10.1093/oxfordjournals.ndt.a027137

54. Teoh CW, Robinson LA, Noone D. Perspectives on edema in childhood nephrotic syndrome. Am J Physiol Renal Physiol. (2015) 309:F575-82. doi: 10.1152/ajprenal.00229.2015

55. Shearer GC, Kaysen GA. Proteinuria and plasma compositional changes contribute to defective lipoprotein catabolism in the nephrotic syndrome by separate mechanisms. Am J Kidney Dis. (2001) 37(1 Suppl. 2):S119-22. doi: 10.1053/ajkd.2001.20766

56. Vaziri ND. Disorders of lipid metabolism in nephrotic syndrome: mechanisms and consequences. Kidney Int. (2016) 90:41-52. doi: 10.1016/j.kint.2016.02.026

57. White RH. The familial nephrotic syndrome. I. A European survey. Clin Nephrol. (1973) 1:215-9.

58. McKinney PA, Feltbower RG, Brocklebank JT, Fitzpatrick MM. Time trends and ethnic patterns of childhood nephrotic syndrome in Yorkshire, UK. Pediatr Nephrol. (2001) 16:1040-4. doi: 10.1007/s004670100021

59. Dorval G, Gribouval O, Martinez-Barquero V, Machuca E, Tête MJ, Baudouin V, et al. Clinical and genetic heterogeneity in familial steroid-sensitive nephrotic syndrome. Pediatr Nephrol. (2018) 33:473-83. doi: 10.1007/s00467-017-3819-9

60. Gee HY, Ashraf S, Wan X, Vega-Warner V, Esteve-Rudd J, Lovric S, et al. Mutations in EMP2 cause childhood-onset nephrotic syndrome. Am J Hum Genet. (2014) 94:884-90. doi: 10.1016/j.ajhg.2014.04.010

61. Roberts ISD, Gleadle JM. Familial nephropathy and multiple exostoses with exostosin-1 (EXT1) gene mutation. JASN (2008) 19:450-3. doi: 10.1681/ASN.2007080842

62. Park E, Chang HJ, Shin JI, Lim BJ, Jeong HJ, Lee KB, et al. Familial IPEX syndrome: different glomerulopathy in two siblings. Pediatr Int. (2015) 57:e59-61. doi: 10.1111/ped.12570

63. Gee HY, Zhang F, Ashraf S, Kohl S, Sadowski CE, Vega-Warner V, et al. KANK deficiency leads to podocyte dysfunction and nephrotic syndrome. J Clin Invest. (2015) 125:2375-84. doi: 10.1172/JCI79504

64. Kitamura A, Tsukaguchi H, Hiramoto R, Shono A, Doi T, Kagami S, et al. A familial childhood-onset relapsing nephrotic syndrome. Kidney Int. (2007) 71:946-51. doi: 10.1038/sj.ki.5002110

65. Lahdenkari AT, Kestilä M, Holmberg C, Koskimies O, Jalanko H. Nephrin gene (NPHS1) in patients with minimal change nephrotic syndrome (MCNS). Kidney Int. (2004) 65:1856-63. doi: $10.1111 / j .1523-1755.2004 .00583 . x$ 
66. Hinkes B, Wiggins RC, Gbadegesin R, Vlangos CN, Seelow D, Nurnberg $\mathrm{G}$, et al. Positional cloning uncovers mutations in PLCE1 responsible for a nephrotic syndrome variant that may be reversible. Nat Genet. (2006) 38:1397-405. doi: 10.1038/ng 1918

67. Ashraf S, Kudo H, Rao J, Kikuchi A, Widmeier E, Lawson JA, et al. Mutations in six nephrosis genes delineate a pathogenic pathway amenable to treatment. Nat Commun. (2018) 9:1960. doi: 10.1038/s41467-018-04193-w

68. Bierzynska A, Soderquest K, Dean P, Colby E, Rollason R, Jones C, et al. MAGI2 mutations cause congenital nephrotic syndrome. J Am Soc Nephrol. (2017) 28:1614-21. doi: 10.1681/ASN.2016040387

69. Ihara K-I, Asanuma K, Fukuda T, Ohwada S, Yoshida M, Nishimori K. MAGI-2 is critical for the formation and maintenance of the glomerular filtration barrier in mouse kidney. Am J Pathol. (2014) 184:2699-708. doi: 10.1016/j.ajpath.2014.06.019

70. Marusugi K, Nakano K, Sasaki H, Kimura J, Yanobu-Takanashi R, Okamura T, et al. Functional validation of tensin2 SH2-PTB domain by CRISPR/Cas9-mediated genome editing. J Vet Med Sci. (2016) 78:1413-20. doi: 10.1292/jvms.16-0205

71. Tensin2-Deficient Mice on FVB/N Background Develop Severe Glomerular Disease. - PubMed - NCBI. Available online at: https://www.ncbi.nlm.nih. gov/pubmed/26854109

72. Elias BC, Das A, Parekh DV, Mernaugh G, Adams R, Yang Z, et al. Cdc42 regulates epithelial cell polarity and cytoskeletal function during kidney tubule development. J Cell Sci. (2015) 128:4293-305. doi: 10.1242/jcs.164509

73. Robins R, Baldwin C, Aoudjit L, Côté J-F, Gupta IR, Takano T. Racl activation in podocytes induces the spectrum of nephrotic syndrome. Kidney Int. (2017) 92:349-64. doi: 10.1016/j.kint.2017.03.010

74. Babelova A, Jansen F, Sander K, Löhn M, Schäfer L, Fork C, et al. Activation of Rac-1 and RhoA contributes to podocyte injury in chronic kidney disease. PLoS ONE (2013) 8:e80328. doi: 10.1371/journal.pone.0080328

75. Clark AGB, Vaughan RW, Stephens HAF, Chantler C, Williams DG, Welsh KI. Genes encoding the $\beta$-chains of HLA-DR7 and HLA-DQw2 define major susceptibility determinants for idiopathic nephrotic syndrome. Clini Sci. (1990) 78:391-7. doi: 10.1042/cs0780391

76. Lagueruela CC, Buettner TL, Cole BR, Kissane JM, Robson AM. HLA extended haplotypes in steroid-sensitive nephrotic syndrome of childhood. Kidney Int. (1990) 38:145-50. doi: 10.1038/ki.1990.179

77. Kobayashi T, Ogawa A, Takahashi K, Uchiyama M. HLA-DQB1 allele associates with idiopathic nephrotic syndrome in Japanese children. Pediatr Int. (1995) 37:293-6. doi: 10.1111/j.1442-200X.1995.tb03317.x

78. Huang Y-Y, Lin F-J, Fu L-S, Lan J-L. HLA-DR, -DQB typing of steroidsensitive idiopathic nephrotic syndrome children in Taiwan. Nephron Clin Pract. (2009) 112:c57-64. doi: 10.1159/000213082

79. Stanescu HC, Arcos-Burgos M, Medlar A, Bockenhauer D, Kottgen A, Dragomirescu L, et al. Risk HLA-DQA1 and PLA(2)R1 alleles in idiopathic membranous nephropathy. N Engl J Med. (2011) 364:616-26. doi: 10.1056/NEJMoa1009742

80. Sekula P, Li Y, Stanescu HC, Wuttke M, Ekici AB, Bockenhauer D, et al. Genetic risk variants for membranous nephropathy: extension of and association with other chronic kidney disease aetiologies. Nephrol Dial Transplant. (2017) 32:325-32. doi: 10.1093/ndt/gfw001

81. Zhou Q, Lee G-S, Brady J, Datta S, Katan M, Sheikh A, et al. A hypermorphic missense mutation in PLCG2, encoding phospholipase $\mathrm{C} \gamma 2$, causes a dominantly inherited autoinflammatory disease with immunodeficiency. Am J Hum Genet. (2012) 91:713-20. doi: 10.1016/j.ajhg.2012.08.006

82. Ombrello MJ, Remmers EF, Sun G, Freeman AF, Datta S, Torabi-Parizi P, et al. Cold urticaria, immunodeficiency, and autoimmunity related to PLCG2 deletions. N Engl J Med. (2012) 366:330-8. doi: 10.1056/NEJMoa1102140

83. Yu P, Constien R, Dear N, Katan M, Hanke P, Bunney TD, et al. Autoimmunity and inflammation due to a gain-of-function mutation in phospholipase $\mathrm{C} \gamma 2$ that specifically increases external $\mathrm{Ca} 2+$ entry. Immunity (2005) 22:451-65. doi: 10.1016/j.immuni.2005.01.018

84. Parker L, Bahat H, Appel MY, Baum DV, Forer R, Pillar N, et al. Phospholipase C-gamma 2 activity in familial steroid-sensitive nephrotic syndrome. Pediatr Res. (2018). doi: 10.1038/s41390-018-0259-6. [Epub ahead of print].

85. Gillies CE, Putler R, Menon R, Otto E, Yasutake K, Nair V, et al. An eQTL landscape of kidney tissue in human nephrotic syndrome. Am J Hum Genet. (2018) 103:232-44. doi: 10.1016/j.ajhg.2018.07.004
86. Yang S-K, Hong M, Zhao W, Jung Y, Baek J, Tayebi N, et al. Genomewide association study of Crohn's disease in Koreans revealed three new susceptibility loci and common attributes of genetic susceptibility across ethnic populations. Gut (2014) 63:80-7. doi: 10.1136/gutjnl-2013-305193

87. Jin Y, Birlea SA, Fain PR, Gowan K, Riccardi SL, Holland PJ, et al. Variant of TYR and autoimmunity susceptibility loci in generalized vitiligo. N Engl J Med. (2010) 362:1686-97. doi: 10.1056/NEJMoa0908547

88. Cusinato DAC, Lacchini R, Romao EA, Moysés-Neto M, Coelho EB. Relationship of CYP3A5 genotype and ABCB1 diplotype to tacrolimus disposition in Brazilian kidney transplant patients. Br J Clin Pharmacol. (2014) 78:364-72. doi: 10.1111/bcp.12345

89. Luo X, Zhu L, Cai N, Zheng L, Cheng Z. Prediction of tacrolimus metabolism and dosage requirements based on CYP3A4 phenotype and CYP3A $5 * 3$ genotype in Chinese renal transplant recipients. Acta Pharmacol Sin. (2016) 37:555-60. doi: 10.1038/aps.2015.163

90. Zhang J-J, Liu S-B, Xue L, Ding X-L, Zhang H, Miao L-Y. The genetic polymorphisms of $\mathrm{POR}^{*} 28$ and CYP3A5*3 significantly influence the pharmacokinetics of tacrolimus in Chinese renal transplant recipients. Int J Clin Pharmacol Ther. (2015) 53:728-36. doi: 10.5414/CP202152

91. Kurzawski M, Dabrowska J, Dziewanowski K, Domanski L, Peruzynska M, Drozdzik M. CYP3A5 and CYP3A4, but not ABCB1 polymorphisms affect tacrolimus dose-adjusted trough concentrations in kidney transplant recipients. Pharmacogenomics (2014) 15:179-88. doi: 10.2217/pgs.13.199

92. Brambila-Tapia AJ-L. MDR1 (ABCB1) polymorphisms: functional effects and clinical implications. Rev Invest Clin. (2013) 65:445-54.

93. Shi W-L, Tang H-L, Zhai S-D. Effects of the CYP3A4*1B Genetic polymorphism on the pharmacokinetics of tacrolimus in adult renal transplant recipients: a meta-analysis. PLoS ONE (2015). Available online at: https://www.ncbi.nlm.nih.gov/pmc/articles/PMC4454552/

94. Li M, Xu M, Liu W, Gao X. Effect of CYP3 A4, CYP3 A5 and ABCB1 gene polymorphisms on the clinical efficacy of tacrolimus in the treatment of nephrotic syndrome. BMC Pharmacol Toxicol. (2018). Available online at: https://www.ncbi.nlm.nih.gov/pmc/articles/PMC5883590/

95. Safan MA, Elhelbawy NG, Midan DA, Khader HF. ABCB1 polymorphisms and steroid treatment in children with idiopathic nephrotic syndrome. $\mathrm{Br} \mathrm{J}$ Biomed Sci. (2017) 74:36-41. doi: 10.1080/09674845.2016.1220707

96. Choi HJ, Cho HY, Ro H, Lee SH, Han KH, Lee H, et al. Polymorphisms of the MDR1 and MIF genes in children with nephrotic syndrome. Pediatr Nephrol. (2011) 26:1981-8. doi: 10.1007/s00467-011-1903-0

97. Mohammed FZ, Zedan MM, El-Hussiny MAB, Barakat LAE-LA, ElEshmawy MAAE-M. ABCB1 gene polymorphism in nephrotic syndrome. Comp Clin Pathol. (2018) 27:1181-9. doi: 10.1007/s00580-018-2719-0

98. Moussa A, Mabrouk S, Hamdouni H, Ajmi M, Tfifha M, Omezzine A, et al. MDR-1 and CYP3A5 polymorphisms in pediatric idiopathic nephrotic syndrome: impact on susceptibility and response to steroids (Preliminary Results). Clin Lab. (2017) 63:1233-42. doi: 10.7754/Clin.Lab.2017.170203

99. Chiou Y-H, Wang L-Y, Wang T-H, Huang S. Genetic polymorphisms influence the steroid treatment of children with idiopathic nephrotic syndrome. Pediatr Nephrol. (2012) 27:1511-7. doi: $10.1007 / s 00467-012-2182-0$

100. Jafar T, Prasad N, Agarwal V, Mahdi A, Gupta A, Sharma RK, et al. MDR-1 gene polymorphisms in steroid-responsive vs. steroid-resistant nephrotic syndrome in children. Nephrol Dialysis Transpl. (2011) 26:396874. doi: $10.1093 / \mathrm{ndt} / \mathrm{gfr} 150$

101. Youssef DM, Attia TA, El-Shal AS, Abduelometty FA. Multi-drug resistance1 gene polymorphisms in nephrotic syndrome: impact on susceptibility and response to steroids. Gene (2013) 530:201-7. doi: 10.1016/j.gene.2013. 08.045

102. Cizmarikova M, Podracka L, Klimcakova L, Habalova V, Boor A, Mojzis J, et al. MDR1 polymorphisms and idiopathic nephrotic syndrome in slovak children: preliminary results. Med Sci Monit. (2015) 21:59-68. doi: 10.12659/MSM.891366

103. Liu J, Wan Z, Song Q, Li Z, He Y, Tang Y, et al. NR3C1 gene polymorphisms are associated with steroid resistance in patients with primary nephrotic syndrome. Pharmacogenomics (2018) 19:45-60. doi: 10.2217/pgs-2017-0084

104. Youssef DM, El-Shal AS, Hussein S, Salah K, Ahmed AERE. Tumor necrosis factor alpha gene polymorphisms and haplotypes in Egyptian $\begin{array}{llll}\text { children with nephrotic syndrome. Cytokine (2018) 102:76-82. } & \text {. }\end{array}$ doi: $10.1016 /$ j.cyto.2017.06.021 
105. Liu H, Shen Q, Xu H, Yang Y. [Significance of polymorphisms in variable number of tandem repeat region of interleukin- 4 gene in recurrence of childhood steroid sensitive nephrotic syndrome]. Zhonghua Er Ke Za Zhi. (2005) 43:431-3.

106. Serdaroglu E, Mir S, Berdeli A, Aksu N, Bak M. ACE gene insertion/deletion polymorphism in childhood idiopathic nephrotic syndrome. Pediatr Nephrol. (2005) 20:1738-43. doi: 10.1007/s00467-005-2010-x

107. Prasun P, Prasad N, Tripathi G, Jafar T, Sharda S, Gulati S, et al. Association of angiotensin-converting enzyme gene I/D polymorphism with steroid responsiveness in childhood nephrotic syndrome. Indian J Nephrol. (2011) 21:26-9. doi: 10.4103/0971-4065.75215

108. Müller-Berghaus J, Kemper MJ, Hoppe B, Querfeld U, Müller-Wiefel DE, Morahan G, et al. The clinical course of steroid-sensitive childhood nephrotic syndrome is associated with a functional IL12B promoter polymorphism. Nephrol Dial Transplant. (2008) 23:3841-4. doi: 10.1093/ndt/gfn395
109. Karp AM, Gbadegesin RA. Genetics of childhood steroidsensitive nephrotic syndrome. Pediatr Nephrol. (2017) 32:1481-8. doi: 10.1007/s00467-016-3456-8

Conflict of Interest Statement: The authors declare that the research was conducted in the absence of any commercial or financial relationships that could be construed as a potential conflict of interest.

Copyright $\odot 2019$ Lane, Cason, Esezobor and Gbadegesin. This is an open-access article distributed under the terms of the Creative Commons Attribution License (CC $B Y)$. The use, distribution or reproduction in other forums is permitted, provided the original author(s) and the copyright owner(s) are credited and that the original publication in this journal is cited, in accordance with accepted academic practice. No use, distribution or reproduction is permitted which does not comply with these terms. 